\title{
Phase transitions in selected Al-Pd-Co alloys during continuous cooling
}

\author{
I. Černičková ${ }^{1}$, L. Ďuriška ${ }^{1}$, M. Drienovský ${ }^{1}$, D. Janičkovič ${ }^{2}$, J. Janovec ${ }^{3 *}$ \\ ${ }^{1}$ Slovak University of Technology in Bratislava, Faculty of Materials Science and Technology in Trnava, \\ Paulínska 16, 91724 Trnava, Slovak Republic \\ ${ }^{2}$ Slovak Academy of Sciences, Institute of Physics, Dúbravská 9, 84511 Bratislava, Slovak Republic \\ ${ }^{3}$ Slovak University of Technology in Bratislava, Vazovova 5, 81243 Bratislava, Slovak Republic
}

Received 3 March 2016, received in revised form 19 June 2017, accepted 21 June 2017

\begin{abstract}
The continuous cooling from $1300{ }^{\circ} \mathrm{C}$ to ambient temperature by a differential thermal analyser was used to estimate the non-equilibrium evolution of phases in alloys $\mathrm{Al}_{67} \mathrm{Pd}_{14.6} \mathrm{Co}_{18.4}$, $\mathrm{Al}_{76} \mathrm{Pd}_{11} \mathrm{Co}_{13}, \mathrm{Al}_{71.7} \mathrm{Pd}_{14.4} \mathrm{Co}_{13.9}$, and $\mathrm{Al}_{67.4} \mathrm{Pd}_{20.6} \mathrm{Co}_{12}$. To compare non-equilibrium and near-equilibrium microstructures, the same alloys were also annealed at $850^{\circ} \mathrm{C}$ for $500 \mathrm{~h}$. Besides the differential thermal analysis, the X-ray diffraction, the scanning electron microscopy including energy dispersive X-ray spectroscopy, and the Vickers microhardness test were used in the investigation. Various combinations of phases $\beta, U, \delta, \varepsilon_{n}, F, \mathrm{Al}_{5} \mathrm{Co}_{2}$, and $\mathrm{Al}_{9} \mathrm{Co}_{2}$ were identified in the alloys; there was no difference between continuously cooled and as-annealed conditions in the phase occurrence. The alloys, as sequenced above, were considered to solidify through phases $\beta+V$ (concurrently), $F, V$, and $\beta$, respectively. Temperature ranges of solidification were also estimated. Based on the experimental results and other available data, the sequences of non-equilibrium phase transitions were proposed for several alloys of the still less-known Al-Pd-Co system.
\end{abstract}

Key words: Al-Pd-Co, continuous cooling, phase characterisation, differential thermal analysis, phase evolution

\section{Introduction}

Complex metallic alloys (CMA) are compositionally simple systems containing besides classical crystalline phases also structurally complex intermetallic phases (SCIP) with giant unit cells. Quasicrystals and quasicrystal approximants present in CMAs are also classified as SCIPs $[1,2]$. SCIPs were observed mainly in binary and ternary CMAs; in special cases also in quaternary or multi-component alloys [3-5]. Recently, the Al-base SCIPs were mostly studied, because of their good scientific potential [1-10] and unique combination of properties, being interesting for practical applications [11-22]. For instance, CMAs are used as coatings or thin films, due to their good oxidation resistance, low coefficient of friction, low adhesion, reduced wetting with water, and high hardness [14-17]. The coatings are often covered with an addi- tional metallic element (e.g. $\mathrm{Ni}, \mathrm{Fe}$ ) to reach higher efficiency protective multilayer $[18,19]$. Several SCIPs are promising candidates for applications in photovoltaics $[12,13]$. The reinforcing effect of fine SCIP particles in composites of various matrices was also reported $[20-22]$.

In the last decades, phase equilibria in ternary Al-Pd-Co alloys with the bulk Al content exceeding 50 at.\% were studied by Yurechko et al. [23] and Črničková et al. [24, 25]. As a result, the authors reported about seven stable ternary phases, $W, Y_{2}, U$, $V, F, C_{2}$, and $\varepsilon$-family (currently known five phases of $\varepsilon$-family are jointly denoted as $\varepsilon_{n}$ in this work) and proposed isothermal sections of the Al-Pd-Co phase diagram at $1050,1000,940,850,790$, and $700^{\circ} \mathrm{C}$. The above findings, however, represent only an introductory basis for a better understanding of the Al-Pd-Co system; the ongoing study of this system is therefore

*Corresponding author: tel.: +421918646072; e-mail address: jozef.janovec@stuba.sk 
reasonable. Practical cognitions are expected, for instance, to elucidate the phase evolution under nonequilibrium conditions, e.g. during continuous cooling from temperatures near the melting point down to the ambient temperature. To reflect the above fact, this work is aimed at the estimation of non-equilibrium sequences of phase transitions in selected Al-Pd-Co alloys during continuous cooling, done by the use of a Differential Thermal Analyser (DTA).

\section{Experimental procedure}

The investigated alloys $\mathrm{Al}_{67} \mathrm{Pd}_{14.6} \mathrm{Co}_{18.4}, \mathrm{Al}_{76}$ $\mathrm{Pd}_{11} \mathrm{Co}_{13}, \mathrm{Al}_{71.7} \mathrm{Pd}_{14.4} \mathrm{Co}_{13.9}$, and $\mathrm{Al}_{67.4} \mathrm{Pd}_{20.6} \mathrm{Co}_{12}$ (to distinguish between them, the bulk $\mathrm{Pd} / \mathrm{Co}$ ratio is also introduced) were produced by arc melting of pure components under argon atmosphere. The purity of Al-, Co-, and Pd-batches was at least 99.95 wt.\%. After casting, the alloys were annealed at $850^{\circ} \mathrm{C}$ for $500 \mathrm{~h}$ (the as-annealed condition in this work) and rapidly cooled in water to preserve their high-temperature microstructures.
The DTA experiments were performed by an NETZCH STA 409 CD simultaneous thermal analyser working at the rate of $10^{\circ} \mathrm{C} \mathrm{min}{ }^{-1}$ under atmosphere of 99.9999 vol.\% Ar. Small pieces of the as-annealed alloys (each weighing about $10 \mathrm{mg}$ ) were exposed to two successive runs between the ambient temperature and $1300^{\circ} \mathrm{C}$. The samples obtained after the second cooling run was finished (the DTA-cooled condition in this work) as well as the as-annealed samples were then characterised by means of the X-ray diffraction (XRD), the scanning electron microscopy (SEM) including energy dispersive X-ray spectroscopy (EDX), and the Vickers microhardness test.

For the microstructure characterisation and the determination of metal compositions of particular constituents a JEOL JSM-7600F scanning electron microscope was used, operating at the acceleration voltage of $20 \mathrm{kV}$ in regimes of secondary electrons (SEI) or backscattered electrons (BEI). The microscope was equipped with an Oxford Instruments X-max 50 spectrometer for EDX, using the INCA software. An X-ray Panalytical Empyrean PIXCel 3D diffractometer with Bragg-Brentano geometry was used for the phase iden-

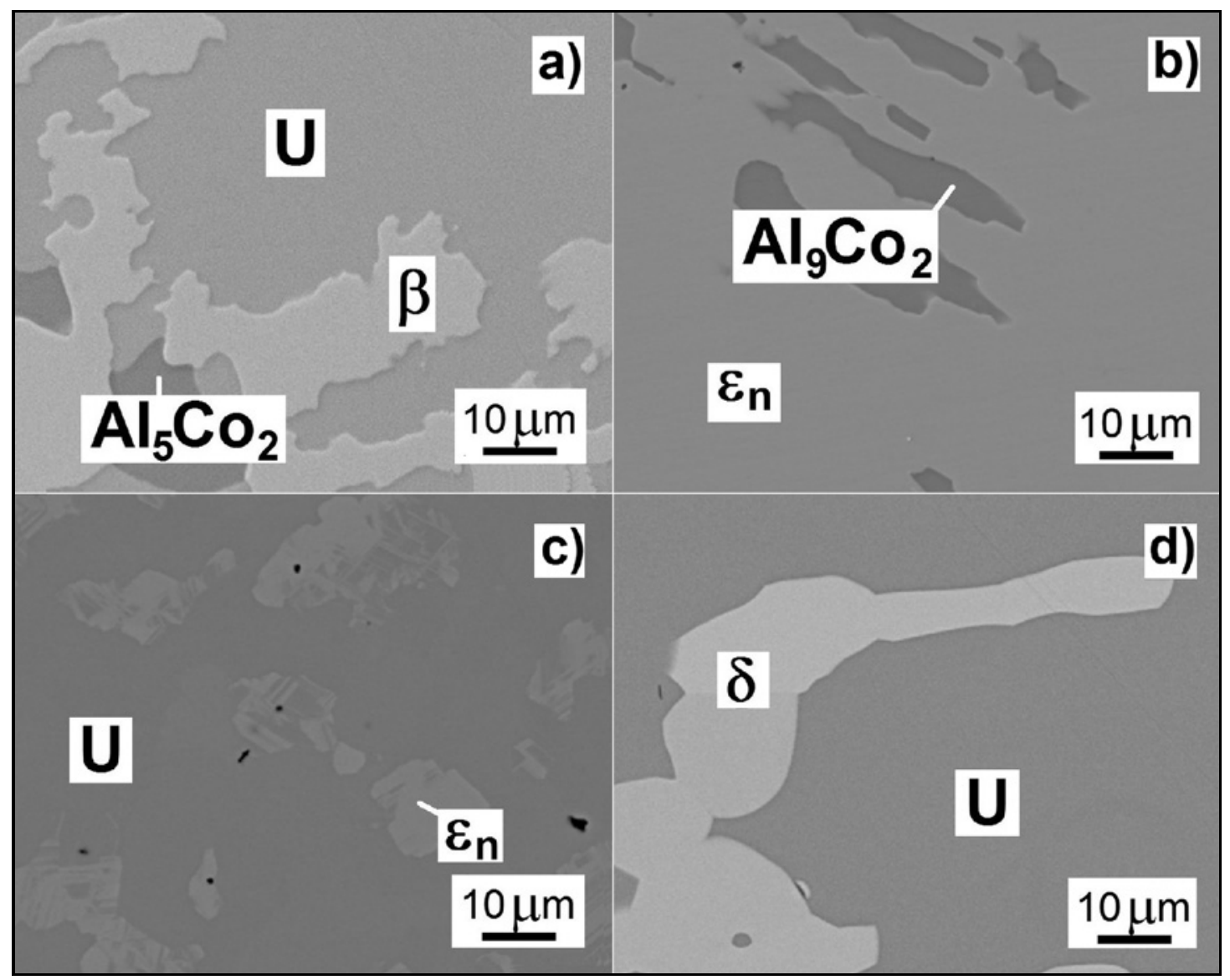

Fig. 1. Characteristic microstructures of alloys $\mathrm{Al}_{67} \mathrm{Pd}_{14.6} \mathrm{Co}_{18.4}$ (a), $\mathrm{Al}_{76} \mathrm{Pd}_{11} \mathrm{Co}_{13}$ (b), $\mathrm{Al}_{71.7} \mathrm{Pd}_{14.4} \mathrm{Co}_{13.9}$ (c), and $\mathrm{Al}_{67.4} \mathrm{Pd}_{20.6} \mathrm{Co}_{12}$ (d). Microstructure constituents are coupled with corresponding phases. Illustrated for DTA-cooled conditions by SEM/BEI imaging. 
Table 1. Basic data about microstructure constituents and phases present in investigated alloys. Negative differences between metal contents of coincident phases are highlighted in grey

\begin{tabular}{|c|c|c|c|c|c|c|c|}
\hline \multirow{2}{*}{$\begin{array}{c}\text { Alloy } \\
(\text { at.\%) }\end{array}$} & \multirow{2}{*}{$\begin{array}{c}\text { Bulk } \\
\text { Pd/Co ratio } \\
\text { (at.\%/at.\%) }\end{array}$} & \multirow{2}{*}{$\begin{array}{c}\text { Micro- } \\
\text { structure } \\
\text { constituent }\end{array}$} & \multirow{2}{*}{ Phase } & \multirow{2}{*}{ Condition } & \multicolumn{3}{|c|}{ Metal contents in phase (at.\%) } \\
\hline & & & & & $\mathrm{Al}$ & $\mathrm{Pd}$ & $\mathrm{Co}$ \\
\hline \multirow{3}{*}{$\mathrm{Al}_{67} \mathrm{Pd}_{14.6} \mathrm{Co}_{18.4}$} & \multirow{3}{*}{0.79} & white & $\beta$ & $\begin{array}{c}\text { as-annealed } \\
\text { DTA-cooled } \\
\text { difference }\end{array}$ & $\begin{array}{c}55.5 \pm 0.1 \\
56.5 \pm 0.5 \\
-1.0\end{array}$ & $\begin{array}{l}24.8 \pm 0.2 \\
20.9 \pm 0.4 \\
\quad+3.9\end{array}$ & $\begin{array}{c}19.7 \pm 0.2 \\
22.6 \pm 0.6 \\
-2.9\end{array}$ \\
\hline & & light grey & $U$ & $\begin{array}{c}\text { as-annealed } \\
\text { DTA-cooled } \\
\text { difference }\end{array}$ & $\begin{array}{c}69.1 \pm 0.2 \\
69.7 \pm 0.6 \\
-0.6\end{array}$ & $\begin{array}{l}14.4 \pm 0.3 \\
12.4 \pm 0.6 \\
\quad+2.0\end{array}$ & $\begin{array}{c}16.5 \pm 0.3 \\
17.9 \pm 0.7 \\
-1.4\end{array}$ \\
\hline & & dark grey & $\mathrm{Al}_{5} \mathrm{Co}_{2}$ & $\begin{array}{c}\text { as-annealed } \\
\text { DTA-cooled } \\
\text { difference }\end{array}$ & $\begin{array}{l}71.1 \pm 0.3 \\
70.8 \pm 0.2 \\
\quad+0.3\end{array}$ & $\begin{array}{c}2.9 \pm 0.3 \\
8.9 \pm 0.3 \\
-6.0\end{array}$ & $\begin{array}{l}26.0 \pm 0.4 \\
20.3 \pm 0.4 \\
\quad+5.7\end{array}$ \\
\hline \multirow{2}{*}{$\mathrm{Al}_{76} \mathrm{Pd}_{11} \mathrm{Co}_{13}$} & \multirow{2}{*}{0.85} & light grey & $\varepsilon_{n}$ & $\begin{array}{c}\text { as-annealed } \\
\text { DTA-cooled } \\
\text { difference }\end{array}$ & $\begin{array}{c}74.8 \pm 0.1 \\
74.9 \pm 0.5 \\
-0.1\end{array}$ & $\begin{array}{c}14.0 \pm 0.2 \\
14.2 \pm 0.4 \\
-0.2\end{array}$ & $\begin{array}{l}11.2 \pm 0.1 \\
10.9 \pm 0.4 \\
\quad+0.3\end{array}$ \\
\hline & & dark grey & $\mathrm{Al}_{9} \mathrm{Co}_{2}$ & $\begin{array}{c}\text { as-annealed } \\
\text { DTA-cooled } \\
\text { difference }\end{array}$ & $\begin{array}{l}82.4 \pm 0.4 \\
81.1 \pm 0.5 \\
\quad+1.3\end{array}$ & $\begin{array}{c}1.8 \pm 0.4 \\
2.9 \pm 0.3 \\
-1.1\end{array}$ & $\begin{array}{c}15.8 \pm 0.3 \\
16.0 \pm 0.4 \\
-0.2\end{array}$ \\
\hline \multirow{2}{*}{$\mathrm{Al}_{71.7} \mathrm{Pd}_{14.4} \mathrm{Co}_{13.9}$} & \multirow{2}{*}{1.04} & light grey & $\varepsilon_{n}$ & $\begin{array}{c}\text { as-annealed } \\
\text { DTA-cooled } \\
\text { difference }\end{array}$ & $\begin{array}{c}72.7 \pm 0.3 \\
72.9 \pm 0.5 \\
-0.2\end{array}$ & $\begin{array}{c}12.7 \pm 0.2 \\
15.2 \pm 0.4 \\
-2.5\end{array}$ & $\begin{array}{l}14.6 \pm 0.1 \\
11.9 \pm 0.6 \\
\quad+2.7\end{array}$ \\
\hline & & dark grey & $U$ & $\begin{array}{c}\text { as-annealed } \\
\text { DTA-cooled } \\
\text { difference }\end{array}$ & $\begin{array}{l}69.8 \pm 0.2 \\
69.4 \pm 0.4 \\
\quad+0.4\end{array}$ & $\begin{array}{l}15.8 \pm 0.1 \\
14.8 \pm 0.6 \\
\quad+1.0\end{array}$ & $\begin{array}{c}14.4 \pm 0.3 \\
15.8 \pm 0.3 \\
-1.4\end{array}$ \\
\hline \multirow{2}{*}{$\mathrm{Al}_{67.4} \mathrm{Pd}_{20.6} \mathrm{Co}_{12}$} & \multirow{2}{*}{1.72} & white & $\delta$ & $\begin{array}{c}\text { as-annealed } \\
\text { DTA-cooled } \\
\text { difference }\end{array}$ & $\begin{array}{l}58.8 \pm 0.4 \\
58.4 \pm 0.5 \\
\quad+0.4\end{array}$ & $\begin{array}{l}40.3 \pm 0.2 \\
37.0 \pm 0.5 \\
\quad+3.3\end{array}$ & $\begin{array}{c}0.9 \pm 0.2 \\
4.6 \pm 0.5 \\
-3.7\end{array}$ \\
\hline & & grey & $U$ & $\begin{array}{c}\text { as-annealed } \\
\text { DTA-cooled } \\
\text { difference }\end{array}$ & $\begin{array}{l}69.5 \pm 0.2 \\
68.8 \pm 0.4 \\
\quad+0.7\end{array}$ & $\begin{array}{c}14.3 \pm 0.2 \\
14.3 \pm 0.6 \\
0\end{array}$ & $\begin{array}{c}16.2 \pm 0.3 \\
16.9 \pm 0.4 \\
-0.7\end{array}$ \\
\hline
\end{tabular}

tification. The characteristic Co $\mathrm{K} \alpha_{1,2}$ radiation was generated at $40 \mathrm{kV}$ and $40 \mathrm{~mA}$. Measurements were done in the angular range $10^{\circ}$ to $140^{\circ}$, with the step size of $0.0131^{\circ}$, and the counting time 98 seconds per step. The Vickers microhardness test was performed by applying loading force of $0.980665 \mathrm{~N}$ (HV0.1) and holding time of $10 \mathrm{~s}$. A Buehler micro indenter IndentaMet 1100 Series was used in testing. To determine average values of HV0.1, 10 indents per constituent were evaluated.

\section{Results}

Characteristic microstructures of the investigated alloys are illustrated in Fig. 1. With the simplification that $\varepsilon_{n}$ is considered as one phase only, the number of observed microstructure constituents is the same as the number of phases identified by XRD for each of the alloys. Accordingly, single-phase constituents only are present in the alloy microstructures. Essential peaks in the XRD patterns are situated between $30^{\circ}$ and $35.5^{\circ}$, as well as between $49.5^{\circ}$ and $55^{\circ}$ that is reflected in Fig. 2 by omitting the central angular range (from about $36^{\circ}$ to $49^{\circ}$ ). In Table 1 , the metal compositions of particular constituents/phases are given, along with the differences between contents of particular elements in coincident phases, i.e. isostructural phases occurring in as-annealed and DTA-cooled conditions of the same alloy. Thus, the negative difference shows the metal content in the as-annealed phase is lower than that in the coincident DTA-cooled phase. In Figs. 1 and 2, the only data corresponding to the DTA-cooled conditions are documented, because of their good coincidence with those obtained for the asannealed conditions. 
Table 2. Average values of microhardness HV0.1, determined for all constituents/phases being observed/identified. To each average value, calculated from ten indents, standard deviation is also attached

\begin{tabular}{|c|c|c|c|c|}
\hline \multirow{2}{*}{$\begin{array}{c}\text { Alloy (at.\%) } \\
\text { and } \\
\text { bulk Pd/Co ratio (at.\%/at.\%) }\end{array}$} & \multirow{2}{*}{$\begin{array}{l}\text { Microstructure } \\
\text { constituent }\end{array}$} & \multirow{2}{*}{ Phase } & \multicolumn{2}{|c|}{ HV0.1 } \\
\hline & & & DTA-cooled & as-annealed \\
\hline \multirow{3}{*}{$\begin{array}{c}\mathrm{Al}_{67} \mathrm{Pd}_{14.6} \mathrm{Co}_{18.4} \\
0.79\end{array}$} & white & $\beta$ & $907 \pm 24$ & $928 \pm 20$ \\
\hline & light grey & $U$ & $720 \pm 17$ & $725 \pm 15$ \\
\hline & dark grey & $\mathrm{Al}_{5} \mathrm{Co}_{2}$ & $626 \pm 9$ & $633 \pm 14$ \\
\hline $\mathrm{Al}_{76} \mathrm{Pd}_{11} \mathrm{Co}_{13}$ & light grey & $\varepsilon_{n}$ & $644 \pm 3$ & $638 \pm 5$ \\
\hline 0.85 & dark grey & $\mathrm{Al}_{9} \mathrm{Co}_{2}$ & $560 \pm 7$ & $556 \pm 8$ \\
\hline $\mathrm{Al}_{71.7} \mathrm{Pd}_{14.4} \mathrm{Co}_{13.9}$ & light grey & $\varepsilon_{n}$ & $632 \pm 12$ & $640 \pm 14$ \\
\hline 1.04 & dark grey & $U$ & $736 \pm 10$ & $728 \pm 9$ \\
\hline $\mathrm{Al}_{67.4} \mathrm{Pd}_{20.6} \mathrm{Co}_{12}$ & white & $\delta$ & $830 \pm 14$ & $834 \pm 12$ \\
\hline 1.72 & grey & $U$ & $731 \pm 8$ & $730 \pm 9$ \\
\hline
\end{tabular}

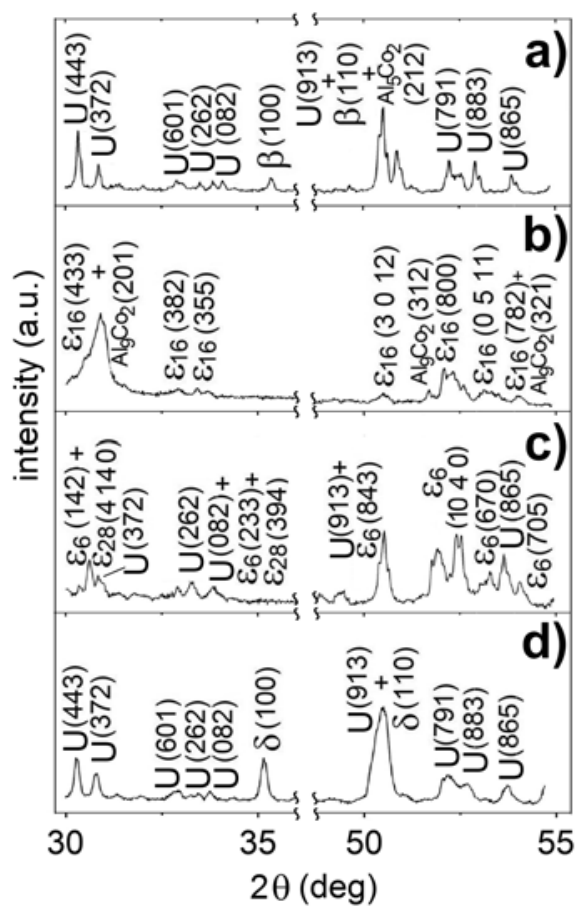

Fig. 2. XRD patterns acquired from DTA-cooled samples of alloys $\mathrm{Al}_{67} \mathrm{Pd}_{14.6} \mathrm{Co}_{18.4}$ (a), $\mathrm{Al}_{76} \mathrm{Pd}_{11} \mathrm{Co}_{13}$ (b), $\mathrm{Al}_{71.7} \mathrm{Pd}_{14.4} \mathrm{Co}_{13.9}$ (c), and $\mathrm{Al}_{67.4} \mathrm{Pd}_{20.6} \mathrm{Co}_{12}$ (d). The central angular range (from about $36^{\circ}$ to $49^{\circ}$ ) was omitted, because of the absence of characteristic peaks.

In the microstructure of the $\mathrm{Al}_{67} \mathrm{Pd}_{14.6} \mathrm{Co}_{18.4}$ alloy, three constituents are present, corresponding to phases $U, \beta$, and $\mathrm{Al}_{5} \mathrm{Co}_{2}$, Figs. 1a and 2a. Ternary $\varepsilon_{16}$ (in Fig. 1b denoted as $\varepsilon_{n}$ ) and binary $\mathrm{Al}_{9} \mathrm{Co}_{2}$ were identified in the $\mathrm{Al}_{76} \mathrm{Pd}_{11} \mathrm{Co}_{13}$ alloy (Fig. 2b). The double-phase microstructure of the $\mathrm{Al}_{71.7} \mathrm{Pd}_{14.4} \mathrm{Co}_{13.9}$ alloy was found to consist of phases $\varepsilon_{6}+\varepsilon_{28}$ (denoted as $\varepsilon_{n}$ ) and $U$, Figs. 1c and 2c. A weaker contrast between hues of constituents in the SEM/BEI image is probably due to the metal composition of coexisting phases, being close to one another (Table 1). The binary phases $\varepsilon_{6}$ and $\varepsilon_{28}$ are not distinguishable metallographically within the common microstructure constituent $\varepsilon_{n}$, but they exhibit different XRD patterns [23], Fig. 2c. In the $\mathrm{Al}_{67.4} \mathrm{Pd}_{20.6} \mathrm{Co}_{12}$ alloy, two well distinguishable constituents were observed, identified as phases $U$ and $\delta$, Figs. $1 \mathrm{~d}$ and $2 \mathrm{~d}$.

The HV0.1 values, given in Table 2 , show a response of particular constituents/phases to a local mechanical loading. The highest HV0.1 values were recorded for phases $\beta$ and $\delta$, containing less $\mathrm{Al}$ (and ergo more $\mathrm{Pd}$ and $\mathrm{Co}$ in total) compared to other phases identified. On the other hand, the lowest HV0.1 values exhibit binary phases $\mathrm{Al}_{5} \mathrm{Co}_{2}$ and $\mathrm{Al}_{9} \mathrm{Co}_{2}$, with limited $\mathrm{Pd}$-contents, and $\varepsilon_{n}$ is having the highest $\mathrm{Al}$ -content of ternary phases (Table 1 ).

In Fig. 3, DTA records of the alloys (always the second runs) are illustrated. For each alloy, the cooling curve was analysed in detail, to extract information about the solidification. If the recorded peak tends to be formed by more mutually overlapped sub-peaks, probable sub-peak positions are estimated and illustrated by narrow solid lines. Principles of the peak denotation are specified in the caption to Fig. 3. For particular maxima, approximate onsets and offsets are estimated and depicted with dashed lines. Details of probable phase transitions derived from the DTA records are summarised in Table 3. Besides the obtained experimental results, the earlier published findings of phase equilibria in the $\mathrm{Al}-\mathrm{Pd}-\mathrm{Co}$ system at $1050,1000,940,850,790$, and $700^{\circ} \mathrm{C}[23-25]$ are also added to Table 3. To denote liquid, the symbol " $\mathrm{L}$ " is used in this work.

\section{Discussion}

As follows from Fig. 3 and Table 3, the microstruc- 


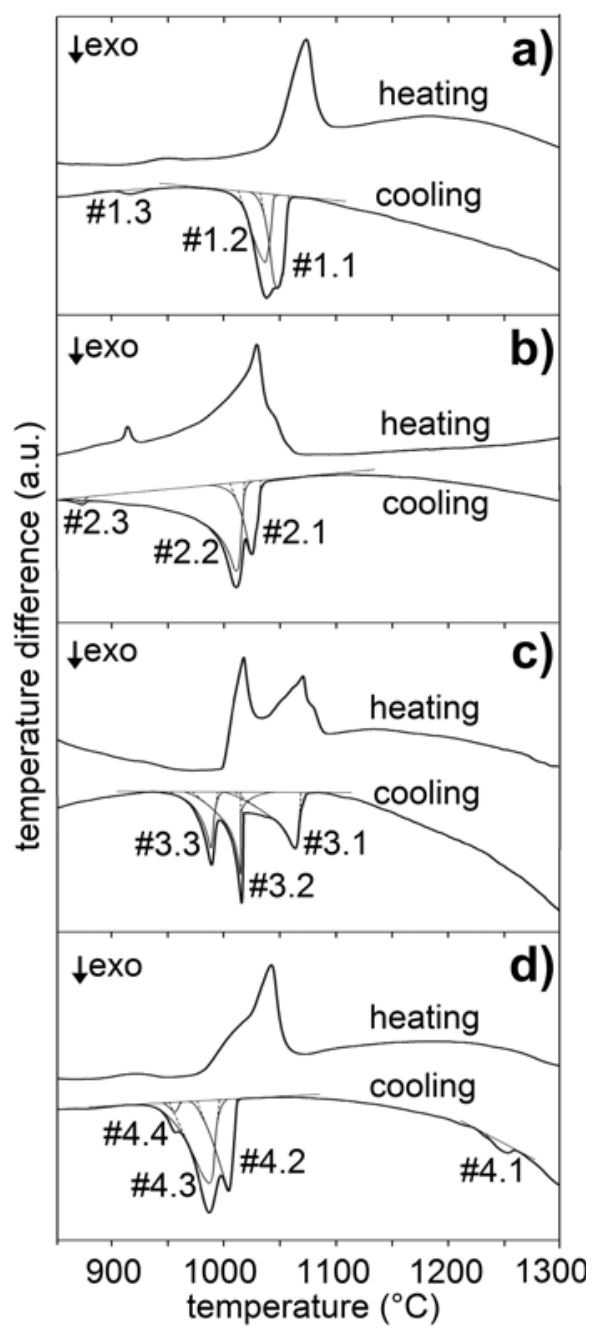

Fig. 3. DTA records of alloys $\mathrm{Al}_{67} \mathrm{Pd}_{14.6} \mathrm{Co}_{18.4}$ (a), $\mathrm{Al}_{76} \mathrm{Pd}_{11} \mathrm{Co}_{13}$ (b), $\mathrm{Al}_{71.7} \mathrm{Pd}_{14.4} \mathrm{Co}_{13.9}$ (c), and $\mathrm{Al}_{67.4} \mathrm{Pd}_{20.6}$ $\mathrm{Co}_{12}$ (d). Analysed peaks are denoted with symbols \#X. $Y$, where $X$ stands for the alloy (the lowest number corresponds to the lowest bulk $\mathrm{Pd} / \mathrm{Co}$ ratio, see also Table 1 , and $Y$ is the peak sequential order (the lowest number corresponds to the highest testing temperature, see also Table 3).

ture formation during continuous alloy cooling was finished at temperatures above $850^{\circ} \mathrm{C}$, namely between 855 and $952^{\circ} \mathrm{C}$ in dependence on the alloy bulk metal composition. On cooling DTA curves (Fig. 3), no thermal effects indicating a phase transformation were observed at temperatures below $855^{\circ} \mathrm{C}$. This shows the non-equilibrium phases present in the DTA-cooled samples (Table 1) were formed at temperatures above $850^{\circ} \mathrm{C}$ and they had been retained unchanged during cooling down to room temperature. Thus, it is admissible to compare the non-equilibrium phase, as specified above, with the coincident near-equilibrium phase identified in the as-annealed (at $850^{\circ} \mathrm{C}$ ) sample of the same alloy (Table 1). From the structure point of view, there were not found any differences between coincident phases (Fig. 2, Table 1). Similarly, the HV0.1 values of the coincident phases differ from each other slightly only (Table 2). Metal compositions of the coincident phases are also comparable; the changes are ranging between -1.0 at. $\%$ and +1.3 at. $\%$ for $\mathrm{Al},-6.0$ at. $\%$ and +3.9 at. $\%$ for $\mathrm{Pd}$, and -3.7 at. $\%$ and +5.7 at. $\%$ for Co. As follows from these data, the smallest differences between coincident phases were observed for $\mathrm{Al}$. On the other hand, the highest $\mathrm{Pd}$-depletion in the DTA-cooled conditions was observed for phases $\beta(+3.9$ at. $\%)$ and $\delta(+3.3$ at. $\%)$ in alloys with highest $\mathrm{Co}\left(\mathrm{Al}_{67} \mathrm{Pd}_{14.6} \mathrm{Co}_{18.4}\right.$, bulk $\mathrm{Pd} / \mathrm{Co}$ ratio $\left.=0.79\right)$ and $\mathrm{Pd}\left(\mathrm{Al}_{67.4} \mathrm{Pd}_{20.6} \mathrm{Co}_{12}, 1.72\right)$ contents, respectively (Table 1 ). The same trend is also observable for the highest Co-enrichment in the DTA-cooled conditions. It shows that the diffusion controlled partitioning of $\mathrm{Pd}$ and $\mathrm{Co}$ between coexisting phases on DTA-cooling, leading to higher differences in metal contents of coincident phases, is restrained in alloys with higher bulk $\mathrm{Pd}$ or $\mathrm{Co}$-contents (i.e. in $\mathrm{Al}_{67} \mathrm{Pd}_{14.6} \mathrm{Co}_{18.4}$ and $\mathrm{Al}_{67.4} \mathrm{Pd}_{20.6} \mathrm{Co}_{12}$ ), Table 1 . On the other hand, $\mathrm{a}$ "freezing" of $\mathrm{Pd}$ in the binary $\mathrm{Al}_{5} \mathrm{Co}_{2}$ phase during DTA-cooling of the $\mathrm{Al}_{67} \mathrm{Pd}_{14.6} \mathrm{Co}_{18.4}$ alloy indicates a para equilibrium reaction [26] accompanying the non-equilibrium evolution of this phase. For $U$ and $\varepsilon_{n}$ in all the alloys, small differences were mostly found in metal compositions of coincident phases (Table 1). Moreover, $U$ and $\varepsilon_{n}$, both identified at least in two alloys, show similar values of HV0.1 across the alloys, Table 2 .

When the identified phases are aligned according to either increasing Al-content or decreasing microhardness (HV0.1), both the sequences are identical, except for the positions of $\mathrm{Al}_{5} \mathrm{Co}_{2}$ and $\varepsilon_{n}$. The former phase containing more $\mathrm{Pd}$ and $\mathrm{Co}$ in total has a lower hardness. This contradiction can be explained probably by the presence of two very similar orthorhombic structures in the areas corresponding to $\varepsilon_{n}$ that enhances the density of lattice imperfections and results, in this way, in a higher resistance to the indenter penetration.

Based on the DTA records (Fig. 3) and available literature data (Table 3 ), sequences of the solidification were estimated for all the alloys. Two monovariant-like transitions participated probably in the solidification of the $\mathrm{Al}_{67} \mathrm{Pd}_{14.6} \mathrm{Co}_{18.4}$ alloy; $L_{\text {part }} \rightarrow \beta+V$ (it started at about $1058^{\circ} \mathrm{C}$ ) and $L_{\text {rest }} \rightarrow V$ (it finished at about $1013^{\circ} \mathrm{C}$ ). In this work, athermal phase transitions during continuous cooling are denoted with a couple of terms; the term adopted from the classification of equilibrium phase transformations (e.g. monovariant) and the affix "-like". The only exception to this rule is a bivariant transition because its course (in term of parent and product phases) is defined unambiguously. The temperature range of solidification for the $\mathrm{Al}_{67} \mathrm{Pd}_{14.6} \mathrm{Co}_{18.4}$ alloy 
Ta ble 3. Overview of probable phase transitions during DTA-cooling in investigated alloys. Symbols highlighted in bold show agreement between phase equilibrium reported in literature and phase occurrence estimated experimentally in this work

\begin{tabular}{|c|c|c|c|c|c|}
\hline $\begin{array}{c}\text { Alloy (at.\%) } \\
\text { and } \\
\text { bulk Pd/Co ratio } \\
\text { (at.\%/at.\%) }\end{array}$ & $\begin{array}{c}\text { Reported } \\
\text { phase equilibrium } \\
{[23-25]}\end{array}$ & $\begin{array}{l}\text { Peak position } \\
\left({ }^{\circ} \mathrm{C}\right)\end{array}$ & $\begin{array}{l}\text { Probable } \\
\text { phase } \\
\text { transition }\end{array}$ & $\begin{array}{l}\text { Phase } \\
\text { occurrence } \\
\text { after } \\
\text { transition }\end{array}$ & $\begin{array}{c}\text { Type } \\
\text { of phase transition }\end{array}$ \\
\hline \multirow{6}{*}{$\begin{array}{c}\mathrm{Al}_{67} \mathrm{Pd}_{14.6} \mathrm{Co}_{18.4} \\
0.79\end{array}$} & & $\begin{array}{c}1058-1033 \\
\text { maximum at } 1047\end{array}$ & $\begin{array}{c}\# 1.1 \\
L_{\mathrm{part}} \rightarrow \beta+V\end{array}$ & $\boldsymbol{L}+\boldsymbol{\beta}+\boldsymbol{V}$ & monovariant-like \\
\hline & $1050^{\circ} \mathrm{C}: \boldsymbol{L}+\boldsymbol{\beta}+\boldsymbol{V}$ & & & & \\
\hline & & $\begin{array}{c}1045-1013 \\
\text { maximum at } 1037\end{array}$ & $\begin{array}{c}\# 1.2 \\
L_{\mathrm{rest}}+V \rightarrow U\end{array}$ & $\boldsymbol{\beta}+\boldsymbol{U}$ & monovariant-like \\
\hline & $\begin{array}{c}1000^{\circ} \mathrm{C}, 940{ }^{\circ} \mathrm{C}: \\
\boldsymbol{\beta}+\boldsymbol{U}\end{array}$ & & & & \\
\hline & & $\begin{array}{c}934-906 \\
\text { maximum at } 918\end{array}$ & $\begin{array}{c}\# 1.3 \\
\beta_{\text {part }} ? U_{\text {part }} \\
\rightarrow \mathrm{Al}_{5} \mathrm{Co}_{2}\end{array}$ & $\boldsymbol{\beta}+\boldsymbol{U}+\mathbf{A l}_{\mathbf{5}} \mathbf{C o}_{\mathbf{2}}$ & $?$ \\
\hline & $\begin{array}{c}850^{\circ} \mathrm{C}, 790^{\circ} \mathrm{C} \\
700^{\circ} \mathrm{C}: \\
\boldsymbol{\beta}+\boldsymbol{U}+\mathbf{A l}_{\mathbf{5}} \mathbf{C o}_{\mathbf{2}}\end{array}$ & & & & \\
\hline \multirow{6}{*}{$\begin{array}{c}\mathrm{Al}_{76} \mathrm{Pd}_{11} \mathrm{Co}_{13} \\
0.85\end{array}$} & $1050^{\circ} \mathrm{C}: L$ & & & & \\
\hline & & $\begin{array}{c}1033-1006 \\
\text { maximum at } 1025\end{array}$ & $\begin{array}{c}\# 2.1 \\
L_{\mathrm{part}} \rightarrow F\end{array}$ & $L+F$ & $\begin{array}{c}\text { bivariant } \\
\text { heterogeneous }\end{array}$ \\
\hline & & $\begin{array}{c}1019-855 \\
\text { maximum at } 1012\end{array}$ & $\begin{array}{c}\# 2.2 \\
L_{\text {part }}+F \rightarrow \varepsilon_{n}\end{array}$ & $L+\varepsilon_{n}$ & monovariant-like \\
\hline & $\begin{array}{c}1000^{\circ} \mathrm{C}, 940^{\circ} \mathrm{C}: \\
\boldsymbol{L}+\boldsymbol{\varepsilon}_{\boldsymbol{n}}\end{array}$ & & & & \\
\hline & & $\begin{array}{c}879-864 \\
\text { maximum at } 874\end{array}$ & $\begin{array}{c}\# 2.3 \\
L_{\mathrm{rest}} \rightarrow \mathrm{Al}_{9} \mathrm{Co}_{2}\end{array}$ & $\varepsilon_{n}+\mathrm{Al}_{9} \mathrm{Co}_{2}$ & $\begin{array}{c}\text { bivariant } \\
\text { heterogeneous }\end{array}$ \\
\hline & $\begin{array}{l}790^{\circ} \mathrm{C}, 700^{\circ} \mathrm{C}: \\
\varepsilon_{n}+\mathbf{A l}_{9} \mathbf{C o}_{2}\end{array}$ & & & & \\
\hline \multirow{6}{*}{$\begin{array}{c}\mathrm{Al}_{71.7} \mathrm{Pd}_{14.4} \mathrm{Co}_{13.9} \\
1.04\end{array}$} & & $\begin{array}{c}1069-1010 \\
\text { maximum at } 1063\end{array}$ & $\begin{array}{c}\# 3.1 \\
L_{\text {part }} \rightarrow V\end{array}$ & $\boldsymbol{L}+\boldsymbol{V}$ & $\begin{array}{c}\text { bivariant } \\
\text { heterogeneous }\end{array}$ \\
\hline & $1050^{\circ} \mathrm{C}: L+V$ & & & & \\
\hline & & $\begin{array}{c}1017-972 \\
\text { maximum at } 1015\end{array}$ & $\begin{array}{c}\# 3.2 \\
L_{\text {part }}+V \rightarrow U+\varepsilon_{n}\end{array}$ & $L+U+\varepsilon_{n}$ & $\begin{array}{l}\text { invariant-like } \\
\text { transition }\end{array}$ \\
\hline & $\begin{array}{c}1000^{\circ} \mathrm{C}: \\
\boldsymbol{L}+\boldsymbol{U}+\boldsymbol{\varepsilon}_{\boldsymbol{n}}\end{array}$ & & & & \\
\hline & & $\begin{array}{c}994-952 \\
\text { maximum at } 988\end{array}$ & $\begin{array}{c}\# 3.3 \\
L_{\text {rest }} \rightarrow ?\left(U, \varepsilon_{n}\right)\end{array}$ & $U+\varepsilon_{n}$ & $?$ \\
\hline & $\begin{array}{c}940^{\circ} \mathrm{C}, 850^{\circ} \mathrm{C}, 790^{\circ} \mathrm{C}, \\
700^{\circ} \mathrm{C}: \boldsymbol{U}+\boldsymbol{\varepsilon}_{\boldsymbol{n}}\end{array}$ & & & & \\
\hline
\end{tabular}


Table 3. (continued)

\begin{tabular}{|c|c|c|c|c|c|}
\hline $\begin{array}{c}\text { Alloy (at.\%) } \\
\text { and } \\
\text { bulk Pd/Co ratio } \\
\text { (at.\%/at.\%) }\end{array}$ & $\begin{array}{c}\text { Reported } \\
\text { phase equilibrium } \\
{[23-25]}\end{array}$ & $\begin{array}{l}\text { Peak position } \\
\left({ }^{\circ} \mathrm{C}\right)\end{array}$ & $\begin{array}{l}\text { Probable } \\
\text { Phase } \\
\text { transition }\end{array}$ & $\begin{array}{l}\text { Phase } \\
\text { occurrence } \\
\text { after } \\
\text { transition }\end{array}$ & $\begin{array}{c}\text { Type } \\
\text { of phase transition }\end{array}$ \\
\hline \multirow{7}{*}{$\begin{array}{c}\mathrm{Al}_{67.4} \mathrm{Pd}_{20.6} \mathrm{Co}_{12} \\
1.72\end{array}$} & & $\begin{array}{c}1259-1233 \\
\text { maximum at } 1250\end{array}$ & $\begin{array}{c}\# 4.1 \\
L_{\text {part }} \rightarrow \beta\end{array}$ & $\boldsymbol{L}+\boldsymbol{\beta}$ & $\begin{array}{c}\text { bivariant } \\
\text { heterogeneous }\end{array}$ \\
\hline & $1050^{\circ} \mathrm{C}: \boldsymbol{L}+\boldsymbol{\beta}$ & & & & \\
\hline & & $\begin{array}{c}1011-976 \\
\text { maximum at } 1004\end{array}$ & $\begin{array}{c}\# 4.2 \\
L_{\text {part }}+\beta \rightarrow U+\delta\end{array}$ & $\boldsymbol{L}+\boldsymbol{U}+\boldsymbol{\delta}$ & $\begin{array}{l}\text { invariant-like } \\
\text { transition }\end{array}$ \\
\hline & $1000^{\circ} \mathrm{C}: \boldsymbol{L}+\boldsymbol{U}+\boldsymbol{\delta}$ & & & & \\
\hline & & $\begin{array}{c}996-951 \\
\text { maximum at } 986\end{array}$ & $\begin{array}{c}\# 4.3 \\
L_{\text {rest }} \rightarrow ? \varepsilon_{n}+(U, \delta)\end{array}$ & $?\left(\varepsilon_{n}+U+\delta\right)$ & $?$ \\
\hline & & $\begin{array}{c}961-947 \\
\text { maximum at } 955\end{array}$ & $\begin{array}{c}\# 4.4 \\
? \varepsilon_{n} \stackrel{(U, \delta)}{\rightarrow}\end{array}$ & $U+\delta$ & $?$ \\
\hline & $\begin{array}{c}940^{\circ} \mathrm{C}, 850^{\circ} \mathrm{C} \\
790^{\circ} \mathrm{C}: \\
\boldsymbol{U}+\boldsymbol{\delta}\end{array}$ & & & & \\
\hline
\end{tabular}

is relatively narrow, about $45^{\circ} \mathrm{C}$ (Table 3 ) that supports the suggestion about the concurrent formation of $\beta$ and $V$ by a monovariant-like reaction. Small \#1.3 peak (Fig. 3a) corresponds to a solid state transformation, leading to the formation of a small amount of binary $\mathrm{Al}_{5} \mathrm{Co}_{2}$ from either $\beta$ only, $U$ only, or both these phases. The $\beta$-phase in this alloy was found to be stable in a huge temperature range delimited by liquidus and room temperatures. The solidification of the $\mathrm{Al}_{76} \mathrm{Pd}_{11} \mathrm{Co}_{13}$ alloy started at $1033^{\circ} \mathrm{C}$, probably with the $F$ formation. In the next step (peak \#2.2, Fig. 2 and Table 3 ), $F$ was replaced by $\varepsilon_{n}$ by monovariantlike phase transition. Finally, the rest of liquid (peak \#2.3) transformed in $\mathrm{Al}_{9} \mathrm{Co}_{2}$ (Fig. 1, Table 1). The temperature range of solidification is about $169^{\circ} \mathrm{C}(\mathrm{Ta}-$ ble 3) that is a similar value as estimated for the $\mathrm{Al}_{71.7} \mathrm{Pd}_{14.4} \mathrm{Co}_{13.9}$ alloy $\left(117^{\circ} \mathrm{C}\right)$ solidifying through $V$. The above finding points to similar behaviour of phases $F$ and $V$ in the Al-Pd-Co system, as it was suggested in Refs. [23-25]. It is very likely that between 1017 and $972{ }^{\circ} \mathrm{C}$, the $\mathrm{Al}_{71.7} \mathrm{Pd}_{14.4} \mathrm{Co}_{13.9}$ alloy overcomes the reaction, $L_{\text {part }}+V \rightarrow U+\varepsilon_{n}$ (peak \#3.2 in Fig. 3), showing features of the invariant-like transition. The available experimental and literature data are not satisfactory to specify both phases taking place in the last step of solidification (peak \#3.3 in Fig. 2) and type of the phase transition. Either monovariant-like or bivariant transitions are possible at the participation of $U$ only, $\varepsilon_{n}$ only, of both these phases. All the phase transitions observed in alloys
$\mathrm{Al}_{76} \mathrm{Pd}_{11} \mathrm{Co}_{13}$ and $\mathrm{Al}_{71.7} \mathrm{Pd}_{14.4} \mathrm{Co}_{13.9}$ were found to be heterogeneous, i.e. at the participation of both liquid and solid phases. Thus, the alloy microstructures were formed during the solidification only; there was not observed any thermal effect in the DTA-records (Figs. 3b and $3 \mathrm{c}$ ) corresponding to a pure solid state transformation. In the DTA-record of the $\mathrm{Al}_{67.4} \mathrm{Pd}_{20.6} \mathrm{Co}_{12}$ alloy four cooling peaks are observable (Fig. 3d) by contrast to the first three alloys exhibiting three peaks only. Another particularity of this alloy resides in the wide temperature range of solidification $\left(308^{\circ} \mathrm{C}\right.$, Table 3 ) caused probably by the high bulk $\mathrm{Pd}$-content (20.6 at.\%), contributing to the stabilisation of the primarily solidified $\beta$ (Table 3 ). The bivariant heterogeneous transition, $L_{\text {part }} \rightarrow \beta(\# 4.1$, Table 3$)$, was followed probably by the invariant-like transition, $L_{\text {part }}+\beta \rightarrow U+\delta(\# 4.2$, Fig. $3 \mathrm{~d})$ starting at $1011^{\circ} \mathrm{C}$ and leading to the formation of the $L+U+\delta$ mixture. Transitions taking place at temperatures below $1000{ }^{\circ} \mathrm{C}$ (peaks \#4.3 and \#4.4 in Fig. $3 \mathrm{~d}$ ) cannot be characterised unambiguously, because of lack of experimental data. It is possible that the reaction \#4.3 is associated with the final step of solidification and the formation of temporary $\varepsilon_{n}$, and the solid state transformation \#4.4 corresponds to the decomposition of temporary $\varepsilon_{n}$. In both these reactions, besides $L$ and $\varepsilon_{n}$, also $U$ and $\delta$ are expected to participate.

Couples of cooling and heating curves in the DTA records (Fig. 3) are in good agreement with each other from the shape point of view. In the DTA-records cor- 
responding to alloys $\mathrm{Al}_{67} \mathrm{Pd}_{14.6} \mathrm{Co}_{18.4}, \mathrm{Al}_{76} \mathrm{Pd}_{11} \mathrm{Co}_{13}$, and $\mathrm{Al}_{71.7} \mathrm{Pd}_{14.4} \mathrm{Co}_{13.9}$ (Figs. 3a-c), two dominant high-temperature exothermic peaks on the cooling curve correspond to one complex peak on the heating curve. In the $\mathrm{Al}_{67.4} \mathrm{Pd}_{20.6} \mathrm{Co}_{12}$ alloy (Fig. $3 \mathrm{~d}$ ), the final stage of the melting (it is opposed to the first stage of solidification through $\beta$, peak \#4.1 in Fig. 3d) appears probably at temperatures above $1300^{\circ} \mathrm{C}$, being out of the temperature range used in the DTA experiment. Thus, a thermal effect (peak) reflecting the final melting, was not recorded. Moreover, three exothermic peaks \#4.2, \#4.3, and \#4.4 on the cooling curve correspond to one complex peak on the heating curve, involving three thermal effects responsible for replacement of phases $U, \delta$, and perhaps also $\varepsilon_{n}$ by phases $\beta$ and $L$ (Table 3 ). The energy criterion was not considered in the DTA record evaluation, because of lack of precise data.

\section{Conclusions}

The phase evolution in alloys $\mathrm{Al}_{67} \mathrm{Pd}_{14.6} \mathrm{Co}_{18.4}$, $\mathrm{Al}_{76} \mathrm{Pd}_{11} \mathrm{Co}_{13}, \mathrm{Al}_{71.7} \mathrm{Pd}_{14.4} \mathrm{Co}_{13.9}$, and $\mathrm{Al}_{67.4} \mathrm{Pd}_{20.6}$ $\mathrm{Co}_{12}$ was investigated during both continuous DTA-cooling (the non-equilibrium condition) and annealing at $850^{\circ} \mathrm{C}$ for $300 \mathrm{~h}$ (the near-equilibrium condition). The obtained results can be summarised as follows:

1. In coincident phases, the same combinations of phases $\beta, U, \mathrm{Al}_{5} \mathrm{Co}_{2}, \delta, \varepsilon_{n}$, and $\mathrm{Al}_{9} \mathrm{Co}_{2}$ were identified. This confirms that the phase evolution on continuous cooling was terminated at temperatures higher than $850^{\circ} \mathrm{C}$

2. Metal compositions of coincident phases are comparable; the changes are ranging between -1.0 at. $\%$ and +1.3 at. $\%$ for $\mathrm{Al},-6.0$ at. $\%$ and +3.9 at. $\%$ for $\mathrm{Pd}$, and -3.7 at. $\%$ and +5.7 at. $\%$ for Co.

3. Microhardness (HV0.1) of particular phases was found to be dependent on their metal compositions. The higher the Pd- and Co-contents in total, the higher the phase microhardness. A negligible exception from this rule was found between $\mathrm{Al}_{5} \mathrm{Co}_{2}$ and $\varepsilon_{n}$ only.

4. The alloys, as sequenced above, were considered to solidify primarily through respective $\beta+V$ (by monovariant-like transition), $F, V$, and $\beta$; the temperature ranges of solidification were estimated to be respectively $45,169,117$, and $308^{\circ} \mathrm{C}$.

5 . Based on available experimental data obtained at room temperature, $V$ and $F$ were considered as high-temperature intermediate ternary phases in the alloys.

6. In the $\mathrm{Al}_{67} \mathrm{Pd}_{14.6} \mathrm{Co}_{18.4}$ alloy, $\beta$ was found to be stable in a huge temperature range delimited by liquidus and room temperatures.

7. The phase transitions observed in alloys
$\mathrm{Al}_{76} \mathrm{Pd}_{11} \mathrm{Co}_{13}$ and $\mathrm{Al}_{71.7} \mathrm{Pd}_{14.4} \mathrm{Co}_{13.9}$ were found to be heterogeneous only; this shows both microstructure formation and solidification of the alloys were finished at the same time.

8. Good agreement was found for all the alloys between positions of corresponding DTA-peaks on cooling and heating curves.

\section{Acknowledgements}

The authors wish to thank the European Regional Development Fund for financial support of the project ITMS:26220120014 "Centre for Development and Application of Advanced Diagnostic Methods in Processing of Metallic and Non-metallic Materials" funded within the Research \& Development Operational Programme, the Scientific Grant Agency of the Ministry of Education, Science, Research and Sport of the Slovak Republic and the Slovak Academy of Sciences for financial support under the contract VEGA-1/0018/15, and the Slovak Research and Development Agency for financial support under the contract APVV-15-0049.

\section{References}

[1] Dubois, J. M.: Journal of Physics of Condensed Matter, 13, 2001, p. 7753 .

[2] Dubois, J. M.: Book Series on Complex Metallic Alloys. Basics of Thermodynamics and Phase Transitions in Complex Intermetallics. Ed.: Belin-Ferré, E. Singapur, World Scientific 2018.

[3] Feuerbacher, M., Thomas, C., Roitsch, S.: Intermetallics, 16, 2008, p. 943 . doi:10.1016/j.intermet.2008.04.012

[4] Kaneko, Y., Maezawa, R., Ishimasa, T.: Journal of Non-Crystalline Solids, $334 \&$ \& 335, 2004, p. 8. doi:10.1016/j.jnoncrysol.2003.11.004

[5] Urban, K., Feuerbacher, M.: Journal of Non-Crystalline Solids, $334 \& 335$, 2004, p. 143. doi:10.1016/j.jnoncrysol.2003.11.029

[6] Scudino, S., Sperling, S., Sakaliyska, M., Thomas, C., Feuerbacher, M., Kim, K. B., Ehrenberg, H., Eckert, J.: Acta Materialia, 56, 2008, p. 1136. doi:10.1016/j.actamat.2007.10.060

[7] Pavlyuchkov, D., Balanetskyy, S., Kowalski, W., Surowiec, M., Grushko, B.: Journal of Alloys and Compounds, 477, 2009, p. L41. doi:10.1016/j.jallcom.2008.11.005

[8] Feuerbacher, M., Balanetskyy, S., Heggen, M.: Acta Materialia, 56, 2008, p. 1849. doi:10.1016/j.actamat.2007.12.023

[9] Balanetskyy, S., Grushko, B., Velikanova, T. Y., Urban, K.: Journal of Alloys and Compounds, 376, 2004, p. 158. doi:10.1016/j.jallcom.2004.01.023

[10] Heggen, M., Feuerbacher, M.: Materials Science and Engineering A, 400, 2005, p. 89. doi:10.1016/j.msea.2004.12.055

[11] Delahaye, J., Brison, J. P., Berger, C., Fourcaudot, G.: Materials Science and Engineering A, 294-296, 2000, p. 580. doi:10.1016/S0921-5093(00)01111-4 
[12] Eisenhammer, T., Haugeneder, A., Mahr, A.: Solar Energy Materials \& Solar Cells, 54, 1998, p. 379. doi:10.1016/S0927-0248(98)00089-0

[13] Eisenhammer, T., Mahr, A., Haugeneder, A., Assmann, W.: Solar Energy Materials \& Solar Cells, 46, 1997, p. 53. doi:10.1016/S0927-0248(96)00097-9

[14] Ledieu, J., Cox, E. J., McGrath, R., Richardson, N. V., Chen, Q., Fournée, V., Lograsso, T. A., Ross, A. R., Caspersen, K. J., Unal, B., Evans, J. W., Thiel, P. A.: Surface Science, 583, 2005, p. 4. doi:10.1016/i.susc.2005.02.012

[15] Popovic, D., Naumovic, D., Bovet, M., Koitzsch, C., Schlapbach, L., Aebi, P.: Surface Science, 492, 2001, p. 304. doi:10.1016/S0039-6028(01)01449-2

[16] Rabson, D. A.: Progress in Surface Science, 87, 2012, p. 253. doi:10.1016/i.progsurf.2012.10.001

[17] Balbyshev, V. N., King, D. J., Khramov, A. N., Kasten, L. S., Donley, M. S.: Thin Solid Films, 447-448, 2004, p. 558. doi:10.1016/j.tsf.2003.07.026

[18] Weisskopf, Y., Erbudak, M., Longchamp, J. N., Michlmayr, T.: Surface Science, 600, 2006, p. 2594. doi:10.1016/j.susc.2006.04.025

[19] Wearing, L. H., Smerdon, J. A., Leung, L., Lograsso, T. A., Ross, A. R., McGrath, R.: Surface Science, 601, 2007, p. 3450. doi:10.1016/j.susc.2007.06.028
[20] Kenzari, S., Bonina, D., Dubois, J. M., Fournée, V.: Materials \& Design, 35, 2012, p. 691. doi:10.1016/j.matdes.2011.10.032

[21] Yadav, T. P., Singh, D., Tiwari, R. S., Srivastava, O. N.: Materials Letters, 80, 2012, p. 5. doi:10.1016/j.matlet.2012.04.034

[22] Cerničková, I., Roščák, L., Ali, F., Kusý, M., Scudino, S., Cička, R., Drienovský, M., Priputen, P., Janovec, J.: Kovove Mater., 50, 2012, p. 327.

[23] Yurechko, M., Grushko, B., Velikanova, T., Urban, K.: Journal of Alloys and Compounds, 337, 2002, p. 172. doi:10.1016/S0925-8388(01)01956-9

[24] Cerničková, I., Duriška, L., Priputen, P., Janičkovič, D., Janovec, J.: Journal of Phase Equilibria and Diffusion, 37, 2016, p. 301. doi:10.1007/s11669-016-0456-0

[25] Černičková, I., Čička, R., Śvec, P., Janičkovič, D., Priputen, P., Janovec, J.: In: Aperiodic Crystals. Chapter 18. Eds.: Schmid, S., Withers, R. L., Lifshitz R. Dordrecht, Springer Science + Business Media 2013.

[26] Bhadeshia, H. K. D. H.: In: Physical Metallurgy. Eds.: Laughlin, D. E., Hono, K. 5th Edition. Amsterdam, Elsevier 2014. 